\title{
Undiscovered Oil and Gas Resources of Low er Silurian Qusaiba-Paleozoic Total Petroleum Systems, Arabian Peninsula
}

\author{
Organic-rich shale of the \\ Lower Silurian Qusaiba \\ M ember of the Qalibah \\ Formation is a prolific source \\ rock for hydrocarbons in four \\ Paleozoic Total \\ Petroleum Systems of the \\ Arabian Peninsula. The U.S. \\ Geological Survey estimates \\ a mean of 37 billion barrels \\ of oil and 808 trillion cubic \\ feet of gas as undiscovered \\ conventional resources in \\ these Qusaiba-sourced \\ Paleozoic Total Petroleum \\ Systems.
}

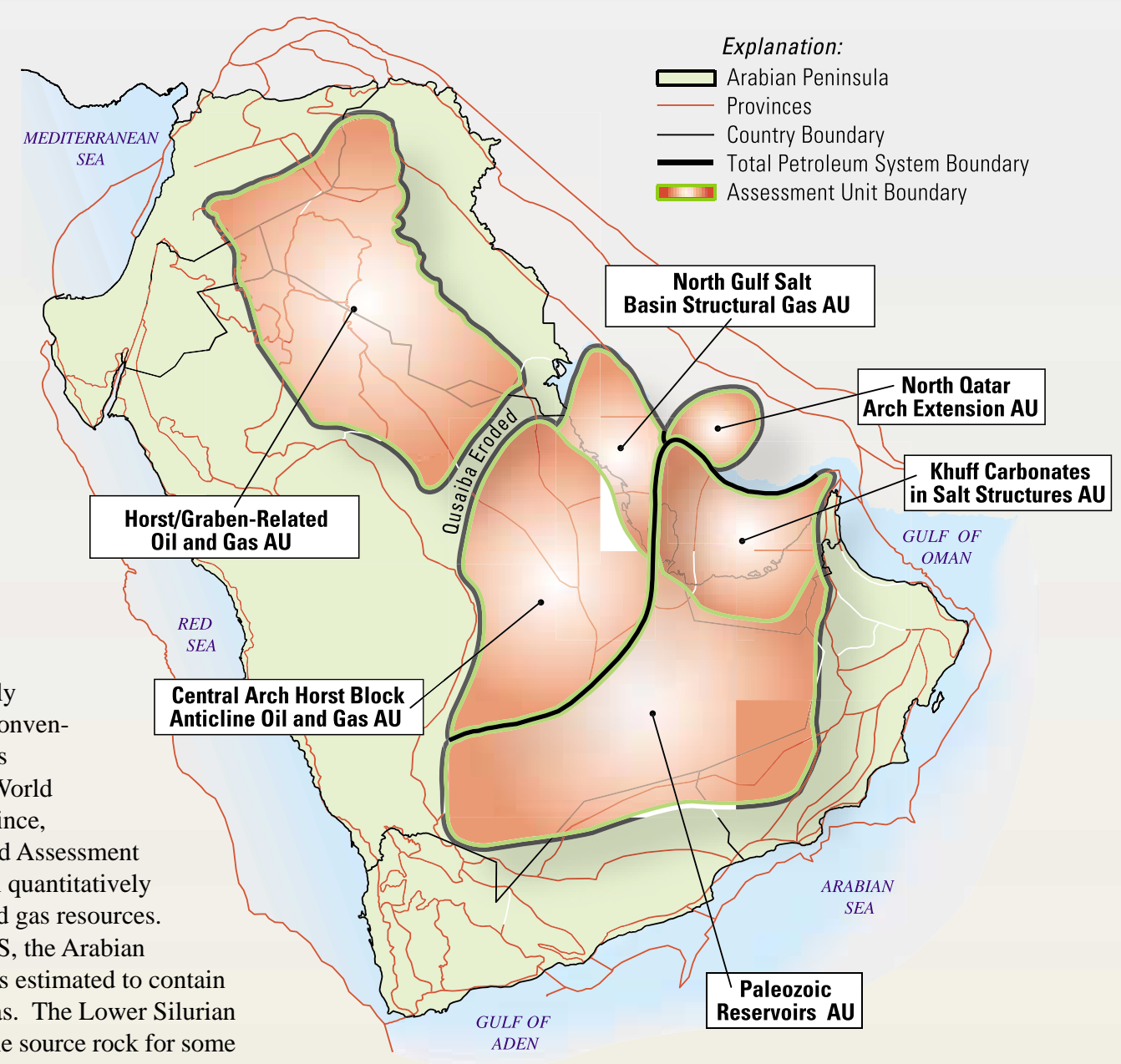

Figure 1. Lower Silurian Qusaiba-Paleozoic Total Petroleum Systems and Assessment Units (AU) of the Arabian Peninsula.

mostly thermally mature for gas generation; however, the Qusaiba is overmature for gas generation in the deeper parts of some basins, and mature for oil generation along some basin margins. The USGS defined six Assessment Units in four regional Lower Silurian Qusaiba-Paleozoic Total Petroleum Systems along the eastern Arabian subcontinent (fig. 1; table 1). Reservoirs in the six Assessment Units are mainly Permian Khuff shelf carbonates along the Arabian-Persian Gulf, and Lower Paleozoic marine and Permian alluvial and eolian sandstones within the interior platform and homocline adjacent to the Arabian Shield (Evans and others, 1997; Aqrawi, 1998; Wender and others, 1998; Sharland and others, 2001). Oil and gas traps are mainly (1) salt-related structural traps, (2) structures related to wrench-fault systems, (3) fault-block anticlinal traps, and (4) sediment drape over pre-existing topography. Stratigraphic traps are common in the Permian clastics in the Central Arabian and Rub' al Khali basins. Exploration for Qusaiba-sourced hydrocarbons of the Arabian Peninsula is generally at an early stage. and others, 1999; Jones and Stump, 1999; Konert and others, 2001). Across the eastern Arabian subcontinent, the Qusaiba hot shale is 
Table 1. Assessment results for Lower Silurian Qusaiba-Paleozoic Total Petroleum Systems.

[M M BO, million barrels of oil. BCFG, billion cubic feet of gas. M M BNGL, million barrels of natural gas liquids. Results shown are fully risked estimates. For gas fields, all liquids are included under the NGL (natural gas liquids) category. F95 represents a 95 percent chance of at least the amount tabulated. Other fractiles are defined similarly. Fractiles are additive only under the assumption of perfect positive correlation. Shading indicates not applicable.]

\begin{tabular}{|c|c|c|c|c|c|c|c|c|c|c|c|c|c|}
\hline \multirow{3}{*}{$\begin{array}{l}\text { Total Petroleum } \\
\text { Systems (TPS) and } \\
\text { Assessment Units (AU) }\end{array}$} & \multirow{3}{*}{$\begin{array}{l}\text { Field } \\
\text { type }\end{array}$} & \multirow{2}{*}{\multicolumn{4}{|c|}{ Oil (MMBO) }} & \multirow{2}{*}{\multicolumn{4}{|c|}{ Gas (BCFG) }} & \multirow[b]{3}{*}{95} & \multirow[b]{3}{*}{50} & \multirow[b]{3}{*}{5} & \multirow[b]{3}{*}{ [rean] } \\
\hline & & & & & & & & & & & & & \\
\hline & & F95 & F50 & F5 & Mean & 95 & 50 & 5 & & & & & \\
\hline \multicolumn{14}{|l|}{ Silurian Qusaiba TPS } \\
\hline \multirow{2}{*}{$\begin{array}{l}\text { Khuff Carbonates } \\
\text { in Salt Structures AU }\end{array}$} & Oil & 0 & 0 & 0 & 0 & 0 & 0 & 0 & 0 & 0 & 0 & 0 & 0 \\
\hline & Gas & & & & & 6,756 & 21,508 & 44,074 & 22,999 & 275 & 320 & 2,062 & 1,012 \\
\hline \multirow{2}{*}{ Paleozoic Reservoirs AU } & Oil & 2,017 & 11,112 & 31,523 & 13,235 & 5,966 & 32,241 & 98,255 & 39,739 & 338 & 1,887 & 6,117 & 2,384 \\
\hline & Gas & & & & & 72,455 & 262,035 & 564,141 & 284,154 & 5,423 & 20,364 & 48,272 & -- \\
\hline \multicolumn{14}{|l|}{ 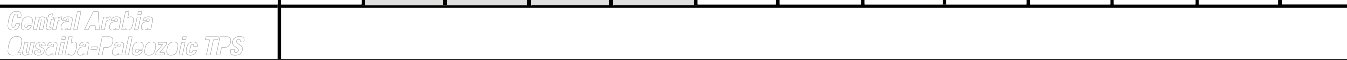 } \\
\hline \multirow{2}{*}{$\begin{array}{l}\text { Central Arch Horst-Block } \\
\text { Anticlinal Oil and Gas AU }\end{array}$} & Oil & 7,301 & 18,596 & 32,829 & 19,190 & 10,587 & 27,514 & 51,123 & 28,756 & 586 & 1,599 & 3,281 & 1,723 \\
\hline & Gas & & & & & 79,478 & 199,003 & 333,005 & 201,631 & 6,238 & 15,742 & 27,327 & 16,138 \\
\hline \multirow{2}{*}{$\begin{array}{l}\text { North Gulf Salt Basin } \\
\text { Structural Gas AU }\end{array}$} & Oil & 0 & 0 & 0 & 0 & 0 & 0 & 0 & 0 & 0 & 0 & 0 & 0 \\
\hline & Gas & & & & & 62,441 & 146,137 & 266,549 & 152,952 & 2,491 & 6,251 & 12,578 & 6,727 \\
\hline \multicolumn{14}{|l|}{ Abba/Mudawwara TPS } \\
\hline \multirow{2}{*}{$\begin{array}{l}\text { Horst/Graben-Related } \\
\text { Oil and Gas AU }\end{array}$} & Oil & 1,530 & 4,605 & 8,038 & 4,682 & 1,128 & 3,570 & 6,952 & 3,748 & 63 & 207 & 446 & 225 \\
\hline & Gas & & & & & 1,192 & 4,584 & 10,052 & 4,993 & 49 & 195 & 471 & \\
\hline \multicolumn{14}{|l|}{$\begin{array}{l}\text { Paleozoic Permian- } \\
\text { Triassic TPS }\end{array}$} \\
\hline \multirow{2}{*}{$\begin{array}{l}\text { North Oatar Arch } \\
\text { Extension AU }\end{array}$} & Oil & 0 & 0 & 0 & 0 & 0 & 0 & 0 & 0 & 0 & 0 & 0 & 0 \\
\hline & Gas & & & & & 20,678 & 64,824 & 131,518 & 69,031 & 839 & 2,763 & 6,138 & 3,039 \\
\hline $\begin{array}{l}\text { Total Conventional } \\
\text { Oil and Gas Resources }\end{array}$ & & 10,848 & 34,313 & 72,390 & 37,107 & 260,681 & 761,416 & $1,505,669$ & 808,003 & 16.302 & 49,328 & 106,692 & 54,218 \\
\hline
\end{tabular}

\section{Summary}

Organic-rich mudstones of the Lower Silurian Qusaiba Member of the Qalibah Formation and equivalent rocks in the Arabian Peninsula are the source of oil and gas for one of the most prolific petroleumgenerating systems in the Middle East region. The USGS estimates a mean of 37 billion barrels of oil and 808 trillion cubic feet of gas of undiscovered conventional resource in six Assessment Units of four Lower Silurian Qusaiba-Paleozoic Total Petroleum Systems across the Arabian Peninsula.

\section{References Cited}

Abu-Ali, M.A., Rudkiewicz, J.L.L., McGillivray, J.G., and Behar, F., 1999, Paleozoic petroleum system of Central Saudi Arabia: GeoArabia, v. 4, p. 321-336

Aqrawi, A.A.M., 1998, Paleozoic stratigraphy and petroleum systems of the western and southwestern deserts of Iraq: GeoArabia, v. 3, p. 229-247.

Bishop, R.S., 1995, Maturation history of the lower Paleozoic of the eastern Arabia Platform, in Al-Husseini, M.I., ed., Geo-94, Middle East Petroleum Geosciences Conference, Gulf PetroLink, Manama, Bahrain, v. 1, p. 180-189.

Cole, G.A., Abu-Ali, M.A., Aoudeh, S.M., Carrigan, M.J., Chen, H.H., Colling, E.L., Gwathney, W.J., Al-Hajii, A.A., Halpern, H.I., Jones, P.J., Al-Sharidi, S.H., and Tobey, M.H., 1994, Organic geochemistry of the Paleozoic petroleum system of Saudi Arabia: Energy and Fuels, v. 8, p. $1425-1442$.

Evans, D.S., Bahabri, B.H., and Al-Otaibi, A.M., 1997, Stratigraphic trap in the Permian Unayzah Formation, central Saudi Arabia: GeoArabia, v. 2, p. 257-278

Jones, P.J., and Stump, T.E., 1999, Depositional and tectonic setting of the Lower Silurian hydrocarbon source facies, central Saudi Arabia: American Association of Petroleum Geologists Bulletin, v. 83, p. 314-332.
Konert, G., Afifi, A., Al-Hajri, S.A, and Droste, H.J., 2001, Paleozoic stratigraphy and hydrocarbon habitat of the Arabian Plate: GeoArabia, v. 6, p. 407-441.

Mahmoud, M.D., Vaslet, D., and Al-Husseini, M.I., 1992, The Lower Silurian Qalibah Formation of Saudi Arabia-an important hydrocarbon source rock: American Association of Petroleum Geologists Bulletin, v. 76, p. 1491-1506.

Milner, P.A., 1998, Source rock distribution and thermal maturity in the southern Arabian Peninsula: GeoArabia, v. 3, p. 339-356.

Sharland, P.R., Casey, D.M., Davies, R.B., Hall, S.H., Heward, A.P., Horbury, A.D., Simmons, M.D., 2001, Arabian plate sequence stratigraphy: GeoArabia Special Publication 2, Gulf PetroLink, Manama, Bahrain, $371 \mathrm{p}$.

U.S. Geological Survey World Energy Assessment Team, 2000, U.S. Geological Survey World Petroleum Assessment 2000-Description and results: U.S. Geological Survey Digital Data Series 60, 4 CD-ROMs.

Wender, L.E., Bryant, J.W., Dickens, M.F., Neville, A.S., and Al-Mogbel, A.M., 1998, Paleozoic (Pre-Khuff) hydrocarbon geology of the Ghawar area, eastern Saudi Arabia: GeoArabia, v. 3, p. 273-301

\section{For more information:}

\section{World Energy Project Chief:}

T.S.Ahlbrandt (ahlbrandt@usgs.gov)

Middle East Petroleum Systems:

R.M. Pollastro（pollastro@usgs.gov)

Rub'al Khali - Paleozoic Assessment:

C.J.Schenk (schenk@usgs.gov)

To access the World Energy Assessment, please go to USGS internet site:

energy.cr.usgs.gov/oilgas/wep 